\title{
Chemical Composition and Antimicrobial Activity of Essential Oil of Citrus limettioides Tanaka
}

\author{
Neeru Vasudeva ${ }^{1 *}$ and Tanu Sharma ${ }^{1}$
}

\begin{abstract}
Aim: The present study is aimed to isolate the essential oil of Citrus limettioides and analyze its chemical composition and antimicrobial potential.

Methods: The essential oil (EO) isolated by hydro-distillation from the peel of fully matured ripen fruits of Citrus limettioides Tanaka and analysed by Gas Chromatography-Mass Spectrometry (GC-MS). The antifungal activity in terms of zone of inhibition and minimum inhibitory concentration (MIC) of the essential oil was tested against ten food borne fungal strains and ten bacterial strains. The EO was also examined for any possible toxicity or adverse effect resulting from its consumption.

Results: Fourteen different components were identified constituting approximately $\geq 99 \%$ of the oil. The major components were dl-limonene (89.089\%), $\beta$-myrcene (2.933\%), ( \pm )-linalool (2.927\%), a-pinene (0.865\%), (E)-citral (0.749\%) etc. According to disc diffusion assay and broth micro-dilution method showed that EO has a wide spectrum of antimicrobial activity against the tested strains with their MIC ranging from $3.12 \mu \mathrm{l} / \mathrm{ml}$ to $50 \mu \mathrm{l} / \mathrm{ml}$.

Conclusion: It can be concluded that EO of Citrus limettioides can be used in skincare formulations for acne control, in treatment of various infectious diseases like typhoid fever, food poisoning, inflammation, sepsis, endocarditis, bladder, prostate and epididymal infections. Along with this it can also be used as safer and alternative means of food preservation. No serious or life-threatening side effects were observed on the haematological and biochemical parameters of mice fed with specific dose of EO of Citrus limettioides, therefore the EO can be recommended as safe fumigant for preservation of food commodities.
\end{abstract}

\section{Background}

Citrus (Rutaceae) is an ancient crop, with records of human cultivation extending back to at least $2100 \mathrm{BC}$ [1]. Citrus fruits are mainly used for dessert, juice and jam production. The food and agro-food processing industry yields considerable amount of waste or by-products such as peels, seeds and pulps which represents $50 \%$ of the raw processed fruit [2]. These by-products are considered as a valuable source of functional ingredients namely flavonoids, dietary fibres and essential oils [3]. EO is one of the citrus by-products attracting keen interest of people [4]. In recent years, the citrus essential oil has been identified in different parts of fruits (preferably in fruit flavedo) as well as in leaves, showing that dl-limonene, $\beta$-myrcene, $\alpha$-pinene, sabinene, $\Delta$-3-carene, a-terpinolene and other elements are the major aromatic compounds of many citrus species [5-14]. These aromatic compounds are relatively inexpensive and abundant raw materials with applications in flavour and food industries [15]. They can also serve as an excellent starting material in the synthesis of fine chemicals and of new fragrances for the cosmetic industry [16]. Moreover, citrus essential oils have been recognised as safe due to their wide spectrum of biological activities such as antimicrobial, antioxidant anti-inflammatory and anxio lytic [17-19]. Due to their great nutraceutical and economic importance, numerous investigations have been performed aimed at identifying

*correspondence: neeruvasudeva@gmail.com 'Department of Pharmaceutical Sciences, Guru Jambheshwar University of Science and Technology, Hisar-125001, (Haryana) India. the chemical composition, antimicrobial activities of the essential oils from peel of different citrus species. In our search for commercially useful essential oils, we selected to study the essential oil of Citrus limettioides Tanaka, as this species has not been investigated for its chemical composition and any biological activity.

\section{Materials \& Methods}

Plant Material The fruits of Citrus limettioides Tanaka commonly known as sweet lime were collected from Guru Jambheshwar University of Science and Technology campus, Hisar. The taxonomic identification of the plant material was confirmed by Dr. H.B. Singh, Head, Raw Materials, Herbarium and Museum Division, National Institute of Science Communication and Information Resources (NISCAIR), New Delhi (India) (2010-11/1519/17). The voucher specimen (No.1011) has been deposited in the Department of Pharmaceutical Sciences for future references.

Animals Swiss albino male mice (weighing 25-30 g) were procured from animal house, CCS, Haryana Agricultural University, Hisar (Haryana), India. The animals were housed under standard environmental conditions $\left(25 \pm 2{ }^{\circ} \mathrm{C}\right.$ temperature and $50 \pm 5 \%$ relative humidity). The animals were acclimatized to laboratory conditions before start of experimental procedures. All procedures were performed under the protocols approved by Institutional Animal Care and Use Committee of Guru Jambheshwar University of Science and Technology, Hisar, Haryana, India (Regn No 0436). 
Vasudeva et al. Journal of Pharmaceutical Technology \& Drug Research 2012,

http://www.hoajonline.com/journals/pdf/2050-120X-1-2.pdf

doi: $10.7243 / 2050-120 \mathrm{X}-1-2$

Essential Oil Extraction and Gas Chromatography-Mass Spectrometry (GC-MS) The fruits of Citrus limettioides were washed and cut into equal portions to remove the peels. The fruit albedo layers were peeled off carefully and discarded and were submitted to hydrodistillation using a Clevenger-type apparatus and extracted with water for $3 \mathrm{~h}$ until no more essential oil was obtained. The essential oil was collected, dried over anhydrous sodium sulphate and stored at $4^{\circ} \mathrm{C}$ in air tight sealed glass vials covered with aluminium foil until used [20]. Gas chromatographic (GC) analysis of the oil obtained from Citrus limettioides was carried out on a Chemito $8510 \mathrm{GC}$ instrument equipped with a data processor. A BP-5 wide-bore capillary column ( $30 \mathrm{~m} \times 0.53 \mathrm{~mm}$ i.d., $1.0 \mu \mathrm{m}$ film thickness) was used for the separation of the sample components (sample size $0.03 \mu \mathrm{l}$, measured using a Hamilton GC syringe of $1.0 \mu \mathrm{l}$ cap.). Hydrogen was used as the carrier gas at a flow rate of $5 \mathrm{ml} / \mathrm{min}$ and 20 p.s.i. inlet pressure. The GC column oven temperature was from $70^{\circ} \mathrm{C}$ to $210^{\circ} \mathrm{C}$ at a rate of $2.5^{\circ} \mathrm{C} / \mathrm{min}$, with a final hold time of $5 \mathrm{~min}$. Both injector and detector (FID) temperatures were maintained at $230^{\circ}$ C. GC-MS analysis was carried out on a Trace DSQ MS (Thermo Electron Corporation), using a BP-5 capillary column (30 m×0.25 mm i.d., $0.5 \mu \mathrm{m}$ film thickness); with helium as the carrier gas at a flow rate of $1 \mathrm{ml} / \mathrm{min}$; split ratio $1: 20$. The column temperature was from $65^{\circ} \mathrm{C}$ to $210^{\circ} \mathrm{C}$ ( $10 \mathrm{~min}$ hold) at $3^{\circ} \mathrm{C} / \mathrm{min}$. Mass spectra were recorded in the range 50-450 amu, operating at $70 \mathrm{eV}$, and the ion source temperature was maintained at $200^{\circ} \mathrm{C}$. The constituents of the oil were identified by using standard reference compounds and also by matching the mass spectra fragmentation pattern with NIST Mass Spectra Library stored in the GC-MS database.

Microbial Strains The bacterial strains; Micrococcus luteus (MTCC 1809), Staphylococcus epidermidis (MTCC 3086), Enterobacter aerogenes (MTCC 2823), Enterococcus faecalis (MTCC 2729), Lactobacillus acidophilus (MTCC 447), Propionibacterium acnes (MTCC 1951), Salmonella typhi (MTCC 1253), Escherichia coli (MTCC 40), Pseudomonas aeruginosa (MTCC 424), Alcaligenes faecalis (MTCC 126) used were procured from the Microbial Type Culture Collection and Gene Bank, Institute of Microbial Technology, Chandigarh, India. The bacterial strains were cultured at $37 \pm 1^{\circ} \mathrm{C}$ for $24 \mathrm{~h}$ in nutrient agar medium, with the exception of Propionibacterium acnes which was cultured at $35^{\circ} \mathrm{C}$ for $48 \mathrm{~h}$ in blood agar base and incubated in anaerobic conditions. The fungal strains; Alternaria alternata (ITCC 6306), Rhizoctonia solani (ITCC6376), Curvularia lunata (ITCC 6257), Fusarium oxysporum (ITCC 6246), Helminthosporium oryzae (ITCC 5559), Aspergillus fumigates (ITCC 1628), Aspergillus niger (ITCC 302), Aspergillus terreus (ITCC 297), Cladosporium herbarum (ITCC 3137), Trichoderma viride (ITCC 6257) used for present study were procured from the Indian Type Culture Collection, Division of Plant Pathology, Indian Agriculture Research Institute, New Delhi, India and were cultured at $29 \pm 1^{\circ} \mathrm{C}$ for 7 days in potato dextrose agar medium. Disc Diffusion Assay The EO was first screened for anti bacterial and anti fungal activity by using agar diffusion technique assay [21]. Filter paper disks (Whatman No.1; $6 \mathrm{~mm}$ diameter) containing $10 \mu \mathrm{l}$ of EO were applied to the surface of various petri-plates containing nutrient agar medium, potato dextrose media and blood agar media previously seeded by spreading $0.1 \mathrm{ml}$ of all bacterial strains (except Propionibacterium acnes), fungal strains and Propionibacterium acnes on the respective medias. The plates were left for $30 \mathrm{~min}$ at room temperature to allow the diffusion of EO before incubation. The bacterial strains were incubated at $37 \pm 1^{\circ} \mathrm{C}$ for $24 \mathrm{~h}$, while Propionobacterium acnes blood agar base media plates were incubated at $35^{\circ} \mathrm{C}$ for $48 \mathrm{~h}$ in anaerobic conditions in anaerobic jars [22] and plates with fungal strains were incubated at $29 \pm 1^{\circ} \mathrm{C}$ for 7 days. Dimethyl sulfoxide (DMSO) served as negative control.

MIC Determination Micro-dilution broth was used for determining MIC for bacteria and fungi, according to NCCLS reference documents M38P, 1998 [23]. A serial dilution of EO was prepared over a range of $3.25 \mu \mathrm{l} / \mathrm{ml}-100 \mu \mathrm{l} / \mathrm{ml}$ in nutrient broth, potato dextrose broth media, blood base broth for all bacterial strains (except Propionibacterium acnes), fungal strains and Propionibacterium acnes respectively. Recent cultures of suspension adjusted to $1-2 \times 10^{3}$ cells $/ \mathrm{ml}$ of bacterial and fungal strains were added to respective media. The bacterial strains were incubated at $37 \pm 1^{\circ} \mathrm{C}$ for 24 hours, while Propionobacterium acnes blood agar base media plates were incubated at $35^{\circ} \mathrm{C}$ for $48 \mathrm{~h}$ in anaerobic conditions in anaerobic jars and plates with fungal strains were incubated at $29 \pm 1^{\circ} \mathrm{C}$ for 7 days. The MIC was defined as the lowest concentration of the essential oil at which the microorganism did not demonstrate any visible growth [24].

Blood Sampling and Clinical Pathology A total number 32 male mice weighing between $25-30 \mathrm{~g}$ were used in this study. Animals were divided into four groups A, B, C and D. Each group consisted of 8 mice. The administration of the EO was done by oral route using a calibrated $1 \mathrm{ml}$ syringe with attached polythene cannula. Group A was given single daily dose of $0.33 \mathrm{ml} / \mathrm{kg}$ volatile oil for 1 week. Group B received single daily dose of $0.33 \mathrm{ml} / \mathrm{kg}$ volatile oil for 2 weeks and Group C was given daily dose of $0.33 \mathrm{ml} / \mathrm{kg}$ volatile oil for 4 weeks. The control group (Group D) was given only distilled water daily for 4 weeks. At the end of each treatment period, the animals were sacrificed by decapitation under light ether anaesthesia. The blood samples were collected and examined for any possible toxicity or adverse effects resulting from consumption of EO. For haematological analysis blood samples were collected from animals into EDTA vacutainer. The parameters tested included haemoglobin, total leukocyte count (TLC), differential leukocyte count (DLC), packed cell volume (PCV), mean corpuscular volume (MCV), mean corpuscular haemoglobin (MCH), mean corpuscular haemoglobin concentration (MCHC). For blood chemistry samples were collected in vacutainers and allowed to coagulate. Serum was separated by centrifugation for $15 \mathrm{~min}$ at $3000 \mathrm{rpm}$. Serum chemistry test included alanine aminotransferase (ALT), aspirate aminotransferase (AST), cholesterol, triglycerides, urea, total proteins, creatinine, blood urea nitrogen (BUN) [25].

Statistical Analysis All the results reported were expressed as mean \pm SEM. All the haematological and biochemical parameters were analysed using one way ANOVA followed by Dunett's test. The significance of all tests was set at $p \leq 0.05$. 


\section{Results \& Discussion}

The EO was colourless to light greenish yellow having fresh, fruity, citrusy and pleasant odour. Its specific gravity, refractive index, optical rotation at $25^{\circ} \mathrm{C}$ were $0.840 \mathrm{~g} / \mathrm{ml}, 1.470$ and $+95.3^{\circ}$ respectively. The boiling point of EO was $175^{\circ} \mathrm{C}$.

Oil Composition the major constituents of EO are shown in Table 1. GC-MS profile depicted that a total of 14 components were present. The monoterpene hydrocarbons constituted the most dominant chemical group and among the monoterpene hydrocarbons dl-limonene (89.098\%) is the largely predominant and specific component followed by $\beta$-myrcene (2.933\%). dllimonene contributes to the aromatic odour of the oil and hence the plants belongs to dl-limonene chemotype. Other monoterpene hydrocarbons were a-pinene $(0.865 \%)$, sabinene $(0.161 \%), \Delta-3$ carene $(0.544 \%)$. Oxygenated monoterpenes were identified as second main group components, among these major ones were (土)-linalool (2.927\%), a-terpineol (0.597\%), (E)-citral (0.749\%) and 4-terpineol (0.169\%), Citronellol (0.304\%) and cis-citral (0.304\%). No sesquiterpene hydrocarbon and oxygenated sesquiterpene were reported. The other oxygenated components were identified as aldehydes components which includes octanal $(0.746 \%)$, decanal (0.335\%) and alcohol component 1-octanol (0.211\%).

Antibacterial Activity The data indicated that EO exhibited varying levels of antibacterial activity against the investigated bacteria. The antibacterial activity potentials were qualitatively and quantitatively

\begin{tabular}{lcc}
\hline Compound & $\begin{array}{c}\text { Retention } \\
\text { Time (min) }\end{array}$ & Yield \% \\
\hline
\end{tabular}

Monoterpene hydrocarbons

$\begin{array}{lcc}\alpha \text { - Pinene } & 6.782 & 0.865 \\ \text { Sabinene } & 8.034 & 0.161 \\ \beta \text { - Myrcene } & 8.626 & 2.933 \\ \delta \text { - 3-Carene } & 9.218 & 0.544 \\ \text { dl-limonene } & 10.073 & 89.089\end{array}$

Oxygenated monoterpenes

$\begin{array}{lll}\text { a- Terpineol } & 15.668 & 0.597 \\ \text { 4- Tepineol } & 15.176 & 0.169 \\ \text { (+-)-Linalool } & 12.508 & 2.927 \\ \text { Citronellol } & 17.018 & 0.304 \\ \text { cis- Citral } & 17.018 & 0.304 \\ \text { (E)- Citral } & 18.438 & 0.749\end{array}$

Other oxygenated compounds

\begin{tabular}{lcc} 
n- Octanal & 9.113 & 0.746 \\
Decanal & 16.123 & 0.335 \\
1-Octanol & 11.566 & 0.211 \\
\hline
\end{tabular}

Table 1. Chemical composition of Citrus limettioides Tanaka essential oil assessed by the inhibition zone diameters and MIC values. The essential oil displayed a variable degree of antibacterial activity on all the tested strains (Fig 1 and 2). The highest antibacterial activity of EO was observed against Propionibacterium acnes with zone of inhibition of $17 \mathrm{~mm}$ followed by Micrococcus luteus, Escherichia coli, Staphylococcus epidermidis and Salmonella typhi with zones of inhibition $10.52 \mathrm{~mm}, 10.05 \mathrm{~mm}, 9.92 \mathrm{~mm}$ and 9.63 $\mathrm{mm}$ respectively. The EO was less effective against Enterobacter aerogenes and Pseudomonas aeruginosa with zone of inhibition $8.29 \mathrm{~mm}$ and $8.51 \mathrm{~mm}$ respectively. The inhibition zones of the EO against Alcaligenes faecalis, Enterococcus faecalis and Lactobacillus acidophilus were $9.1 \mathrm{~mm}, 9.32 \mathrm{~mm}$ and $9.51 \mathrm{~mm}$ respectively. The minimum inhibitory concentrations were observed in the range from 3.12- $50 \mu \mathrm{l} / \mathrm{ml}$. Propionibacterium acnes showed maximum susceptibility to the investigated EO with MIC value of $3.12 \mu \mathrm{l} /$ $\mathrm{ml}$. Escherichia coli and Enterococcus faecalis showed MIC value of $6.25 \mu \mathrm{l} / \mathrm{ml}$. Weak inhibitory effect of EO was observed against Enterobacter aerogenes with MIC value of $50 \mu \mathrm{l} / \mathrm{ml}$. Micrococcus luteus, Salmonella typhi, Staphylococcus epidermidis, Pseudomonas aeruginosa, Alcaligenes faecalis and Lactobacillus acidophilus showed similar susceptibility to the investigated EO with MIC of $12.5 \mu \mathrm{l} / \mathrm{ml}$. DMSO used as a negative control.

Antifungal Activity the antifungal activity in terms of zone of inhibition and minimum inhibitory concentration of EO of Citrus limettioides was tested against ten fungal strains viz. Alternaria alternata, Rhizoctonia solani, Curvularia lunata, Fusarium oxysporum, Helminthosporium oryzae, Aspergillus fumigatus, Aspergillus niger Aspergillus terreus, Cladosporium herbarum and Trichoderma viride. The EO of Citrus limettioides exhibited varying antifungal activity against the various test strains (Fig 3 and 4). The highest antifungal activity of this essential oil was observed against Fusarium oxysporum (zone of inhibition of $10.23 \mathrm{~mm}$ ) followed by Aspergillus niger, Aspergillus fumigatus with zone of inhibition of $9.9 \mathrm{~mm}$ and $9.32 \mathrm{~mm}$ respectively. The zone of inhibition shown by EO against Curvularia lunata, Aspergillus terreus and Trichoderma viride was moderate (zone of inhibition $8.63 \mathrm{~mm}, 8.65 \mathrm{~mm}$ and $8.56 \mathrm{~mm}$ respectively). However, Rhizoctonia solani, Helminthosporium oryzae and Cladosporium herbarum were resistant to the EO. The minimum inhibitory concentrations were observed in the range from 6.25$25 \mu \mathrm{l} / \mathrm{ml}$. Aspergillus niger showed maximum susceptibility to the investigated EO with MIC value of $6.25 \mu \mathrm{l} / \mathrm{ml}$. Weak inhibitory effect of the essential oil was observed against Aspergillus terreus with MIC value of $25 \mu \mathrm{l} / \mathrm{ml}$. Alternaria alternata, Curvularia lunata, Fusarium oxysporum, Aspergillus fumigatus, Trichoderma viride showed similar susceptibility to the investigated essential oil with MIC of $12.5 \mu \mathrm{l} /$ $\mathrm{ml}$. In accordance with the results from disc diffusion method, Rhizoctonia solani, Helminthosporium oryzae and Cladosporium herbarum were resistant to the peel EO of Citrus limettioides. The chemical compounds like linalool, a-pinene, a-terpineol have antifungal and antibacterial activity which are found in appreciable amounts in C. limettioides oil [26]. Citral one of the components of EO of $C$. limettioides acts as a fungicidal agent because it is able to 


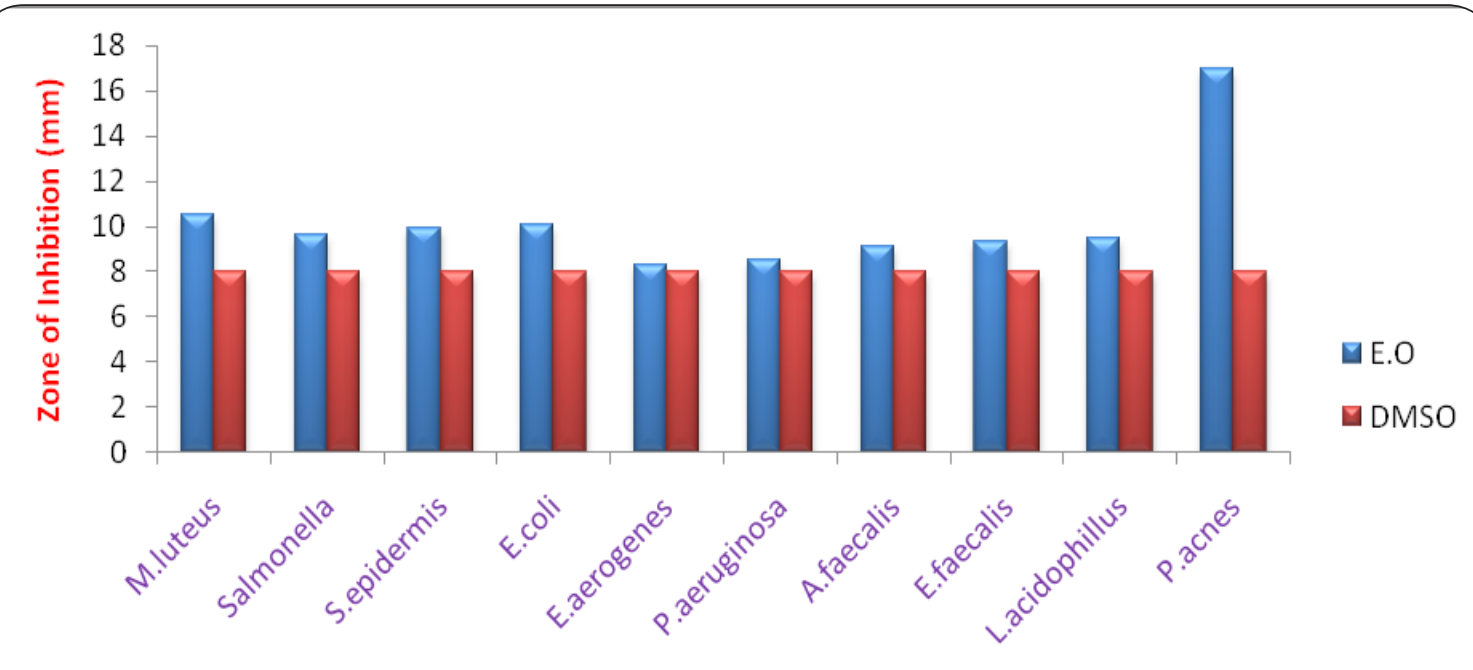

Bacterial Strains

Figure 1. Zone of inhibition for the essential oil of Citrus limettioides Tanaka and DMSO against various bacterial strains

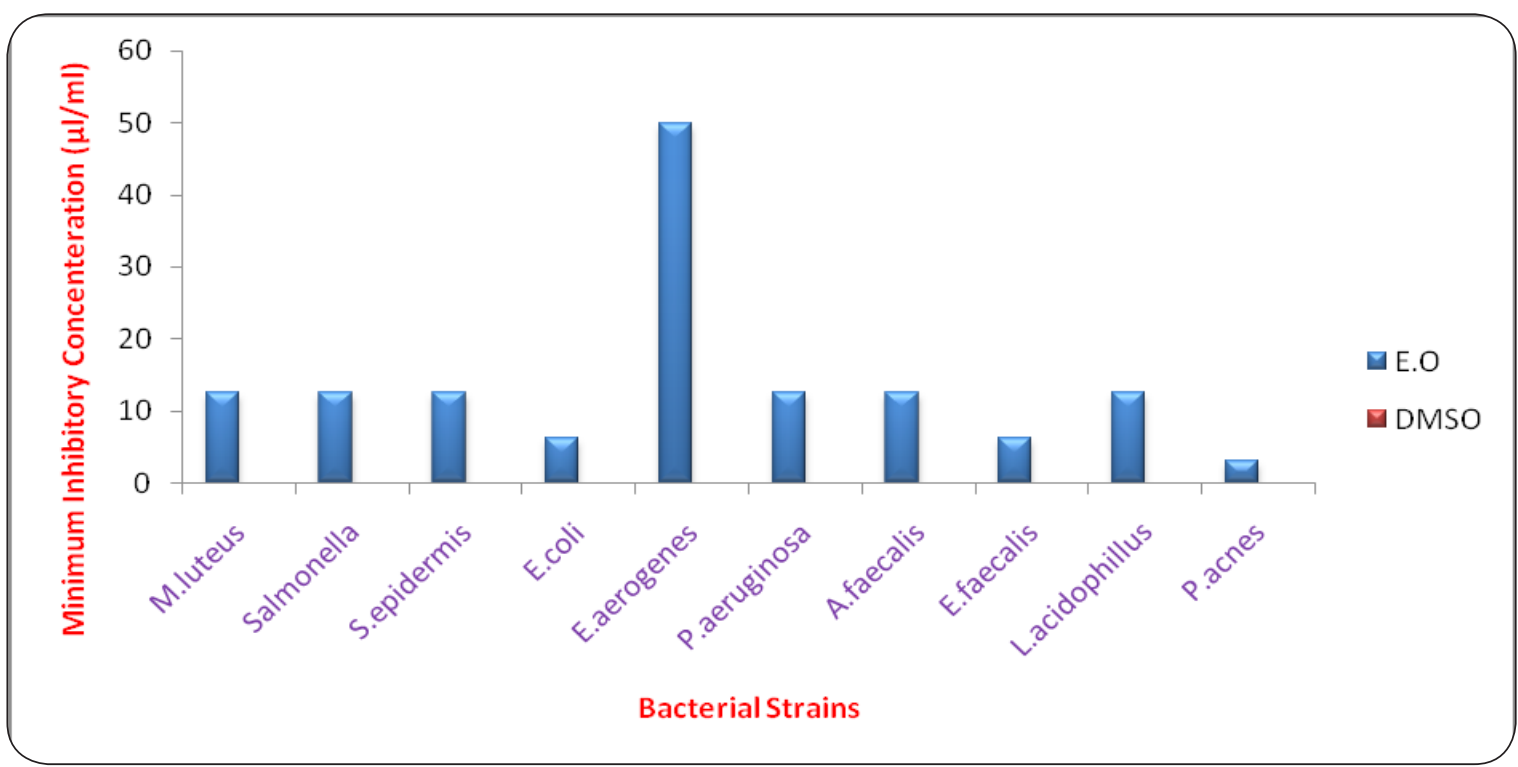

Figure 2. Minimum inhibitory concentration for the essential oil of Citrus limettioides Tanaka and DMSO against various bacterial strains 


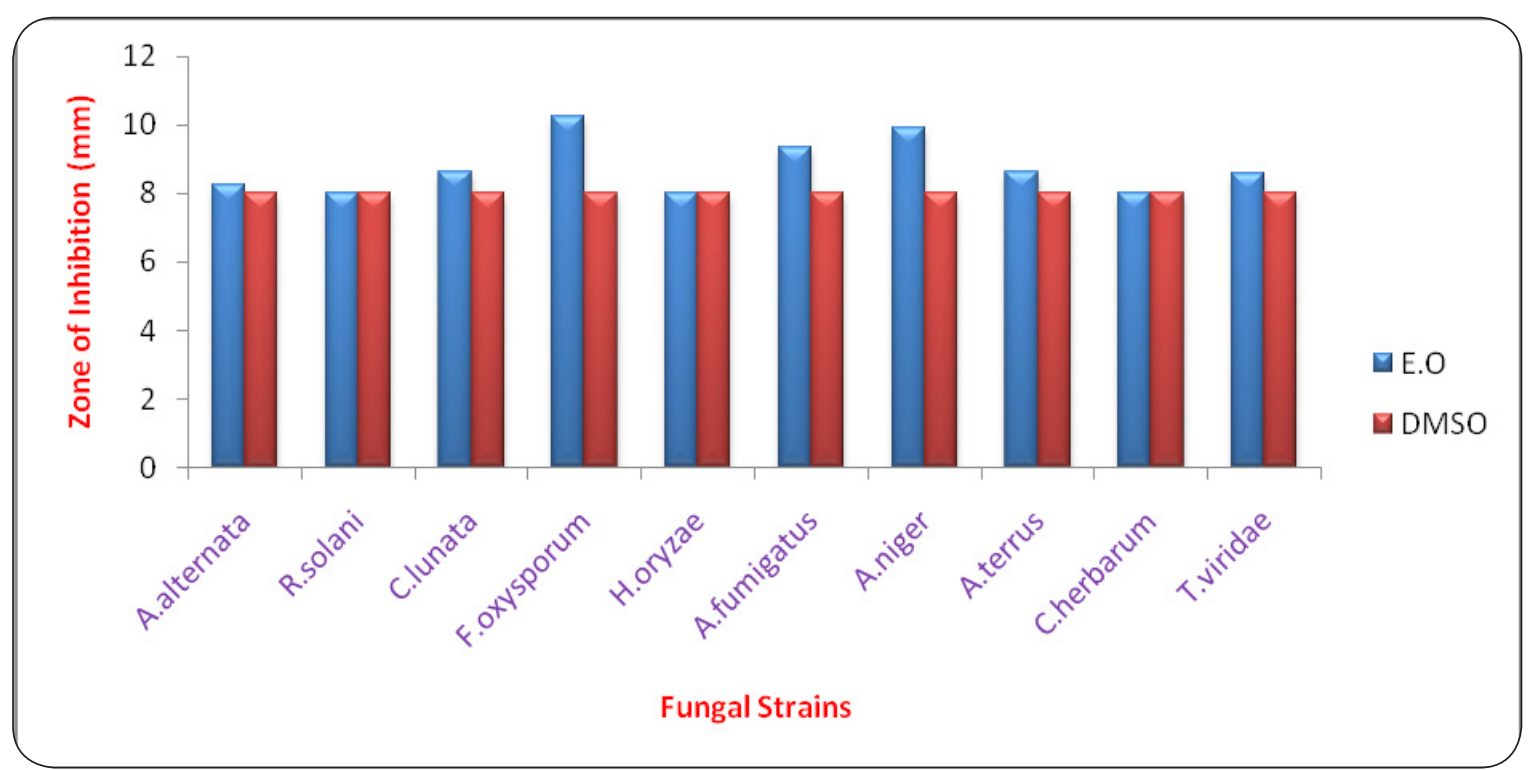

Figure 3. Zone of inhibition for the essential oil of Citrus limettioides Tanaka and DMSO against various fungal strains

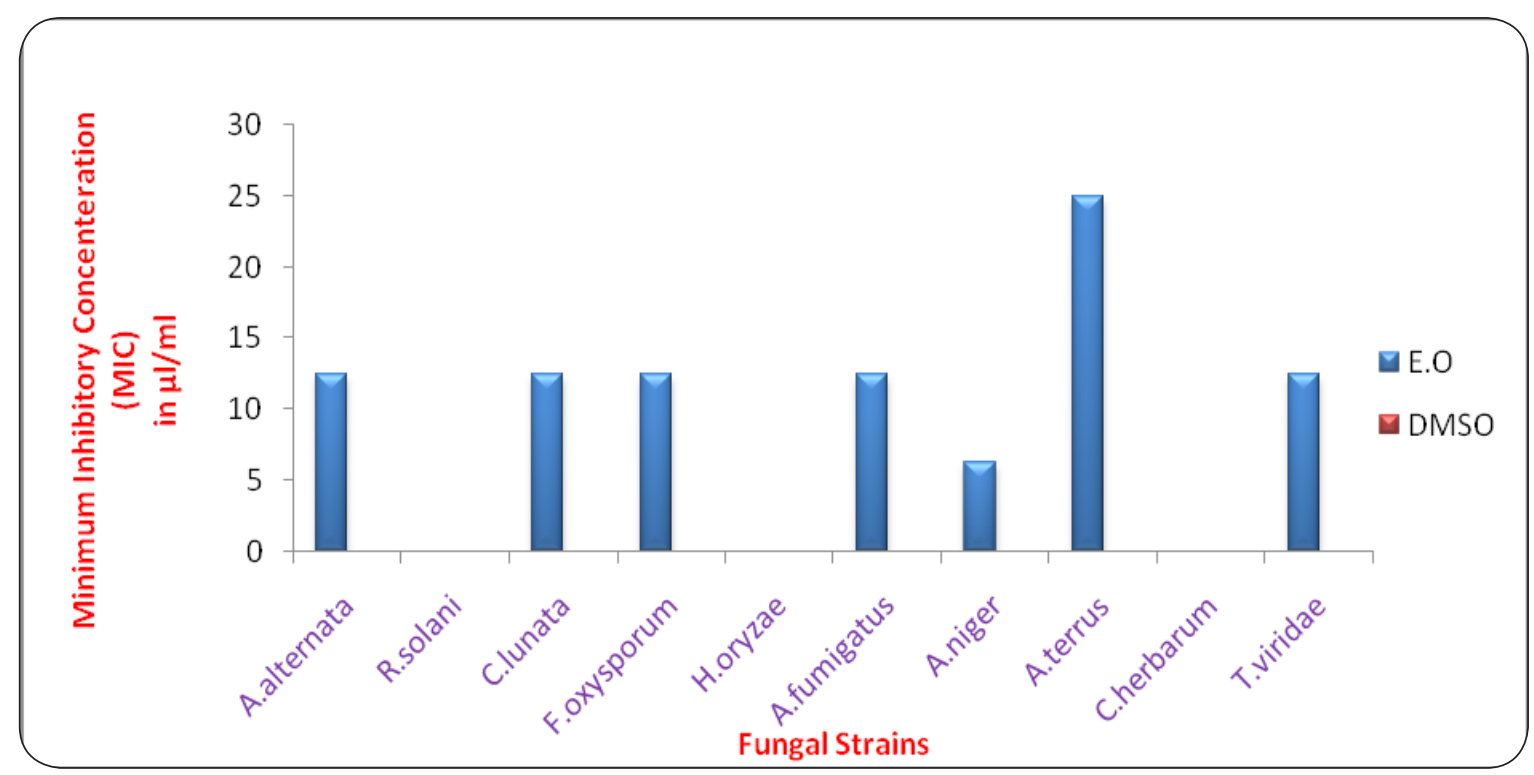

Figure 4.Minimum inhibitory concentration for the essential oil of Citrus limettioides Tanaka and DMSO against various fungal strains 
form a charge transfer complex with an electron donor to fungal cells, which results in fungal death [27].

Toxicology Related to Treatments Blood is an important medium in assessing the health status. Both the physiological and pathological conditions of animals can be assessed by the evaluation of haematological and biochemical analyses of the blood [28-29]. Haematological analyses provide information about the hematopoietic system and immunological responses [28]. The various serum biochemical estimations reflect the normal or abnormal functioning of the various organs of the animal. No clinical signs of abnormal behaviour or toxicity were observed in mice after a 4 week administration of EO. There were no treatment related adverse effects observed on the basis of haematology (Table 2) and blood chemistry (Table 3), hence the EO is very safe and does not affect any essential organ if taken for long period.

It can be concluded that EO of Citrus limettioides can be used in skincare formulations for acne control, in treatment of various infectious diseases like typhoid fever, food poisoning, inflammation, sepsis, endocarditis, bladder, prostate and epididymal infections. Along with this it can also be used as safer and alternative means of food preservation to minimise microbial contamination and to improve the quality of foods as shift from synthetic chemicals to

\begin{tabular}{|c|c|c|c|c|c|}
\hline \multicolumn{2}{|c|}{ Parameter } & $\begin{array}{c}\text { Group } \\
\text { A }\end{array}$ & $\begin{array}{c}\text { Group } \\
\text { B }\end{array}$ & $\begin{array}{c}\text { Group } \\
\text { C }\end{array}$ & $\begin{array}{c}\text { Group } \\
\text { D }\end{array}$ \\
\hline \multicolumn{2}{|c|}{ MCV (fl) } & $\begin{array}{c}43.65 \pm \\
0.65\end{array}$ & $\begin{array}{c}47.34 \pm \\
2.87\end{array}$ & $\begin{array}{c}44.56 \pm \\
1.32\end{array}$ & $\begin{array}{c}44.12 \pm \\
4.55\end{array}$ \\
\hline \multicolumn{2}{|c|}{$\mathrm{MCHC}(\mathrm{g} / \mathrm{dL})$} & $\begin{array}{c}39.45 \pm \\
3.55\end{array}$ & $\begin{array}{c}37.77 \pm \\
1.01\end{array}$ & $\begin{array}{c}40.14 \pm \\
0.61\end{array}$ & $\begin{array}{c}38.23 \pm \\
1.69\end{array}$ \\
\hline \multicolumn{2}{|c|}{$\mathrm{MCH}(\mathrm{pg})$} & $\begin{array}{c}12.06 \pm \\
3.99\end{array}$ & $\begin{array}{c}14.17 \pm \\
0.41\end{array}$ & $\begin{array}{c}16.11 \pm \\
1.62\end{array}$ & $\begin{array}{c}13.43 \pm \\
0.83\end{array}$ \\
\hline \multicolumn{2}{|l|}{ PCV \% } & $\begin{array}{c}36.03 \pm \\
1.09\end{array}$ & $\begin{array}{c}38.54 \pm \\
2.56\end{array}$ & $\begin{array}{c}37.32 \pm \\
0.34\end{array}$ & $\begin{array}{c}39.05 \pm \\
3.45\end{array}$ \\
\hline \multicolumn{2}{|c|}{$\begin{array}{l}\text { Hemoglobin (g/ } \\
\text { dL) }\end{array}$} & $\begin{array}{r}13.065 \\
\pm 0.392\end{array}$ & $\begin{array}{l}13.92 \pm \\
0.6585\end{array}$ & $\begin{array}{c}13.61 \pm \\
0.461\end{array}$ & $\begin{array}{l}13.58 \pm \\
0.4549\end{array}$ \\
\hline \multicolumn{2}{|c|}{$\mathrm{TLC}(/ \mathrm{mm} 3)$} & $\begin{array}{l}9800 \pm \\
152.75\end{array}$ & $\begin{array}{l}8820 \pm \\
222.34\end{array}$ & $\begin{array}{l}8026 \pm \\
205.78\end{array}$ & $\begin{array}{l}8638 \pm \\
430.31\end{array}$ \\
\hline \multirow{4}{*}{$\begin{array}{l}\mathrm{DLC}(/ \\
\mathrm{mm} 3)\end{array}$} & $\begin{array}{l}\text { Neutro- } \\
\text { phils }\end{array}$ & $\begin{array}{c}22.9 \pm \\
1.167\end{array}$ & $\begin{array}{c}20.6 \pm \\
2.081\end{array}$ & $\begin{array}{c}19.7 \pm \\
1.658\end{array}$ & $\begin{array}{c}24.3 \pm \\
1.633\end{array}$ \\
\hline & $\begin{array}{l}\text { Lympho- } \\
\text { cytes }\end{array}$ & $\begin{array}{l}84.25 \pm \\
2.786\end{array}$ & $\begin{array}{c}79.87 \pm \\
3.016\end{array}$ & $\begin{array}{l}73.98 \pm \\
2.012\end{array}$ & $\begin{array}{l}75.66 \pm \\
2.603\end{array}$ \\
\hline & $\begin{array}{l}\text { Mono- } \\
\text { cytes }\end{array}$ & $\begin{array}{l}1.1 \pm \\
0.122\end{array}$ & $\begin{array}{c}1.5 \pm \\
0.50\end{array}$ & $\begin{array}{l}1.3 \pm \\
0.301\end{array}$ & $\begin{array}{l}1.5 \pm \\
0.288\end{array}$ \\
\hline & $\begin{array}{l}\text { Eosino- } \\
\text { phils }\end{array}$ & $\begin{array}{c}1.49 \pm \\
0.016\end{array}$ & $\begin{array}{l}1.5 \pm \\
0.049\end{array}$ & $\begin{array}{l}1.7 \pm \\
0.012\end{array}$ & $\begin{array}{l}1.6 \pm \\
0.057\end{array}$ \\
\hline
\end{tabular}

Table 2. Time dependent effects of essential oil of Citrus limettioides Tanaka on haematological parameters in mice at $0.33 \mathrm{ml} / \mathrm{kg}$ botanical antimicrobials is gaining popularity because of their environment safety and bio-rational mode of action. No serious or life-threatening side effects were observed on the haematological and biochemical parameters of mice fed with specific dose of EO of Citrus limettioides.

\section{Conclusion}

The EO can be recommended as safe fumigant for preservation of food commodities.

\section{Competing interests}

The authors declare that they have no competing interests

\section{Article history}

Received: 23-Feb-2012 Revised: 03-Mar-2012

Accepted: 03-Mar-2012 Published: 27-Mar-2012

\section{References}

1. Moore GA: Oranges and lemons: clues to the taxonomy of Citrus from molecular markers. Trends Genet 2001; 17;(9.);536-40

2. Anwar F, Physico-chemical characteristics of citrus seeds and seed oils from Pakistan. J Am Oil Chem Soc 85: 321-330.

3. Senevirathne $M$, Effective drying of citrus by-product by high speed drying: A novel drying technique and their antioxidant activity. J Food Engineering 92: 157-163.

4. Njoroge SM, Volatile constituents of redblush grapefruit (Citrus paradisi) and pummel (Citrus grandis) peel essential oils from Kenya. J Agric Food Chem 53: 9790-9794.

\begin{tabular}{lcccc}
\hline \multirow{1}{*}{ Parameter } & Group & Group & Group & Group \\
& A & B & C & D \\
\hline Urea $(\mathrm{mg} / \mathrm{dl})$ & $19.63 \pm$ & $20.31 \pm$ & $22.50 \pm$ & $19.07 \pm$ \\
& 1.15 & 1.70 & 1.31 & 1.10 \\
ALT (U/l) & $26.02 \pm$ & 24.74 & $23.61 \pm$ & $25.14 \pm$ \\
& 6.09 & \pm 5.22 & 5.37 & 4.64 \\
AST (U/l) & $70.35 \pm$ & $68.55 \pm$ & $66.98 \pm$ & $72.22 \pm$ \\
Triglyceride (mg/ & 101.02 & 105.83 & 107.44 & $86.09 \pm$ \\
dL) & \pm 12.82 & \pm 13.09 & \pm 12.91 & 12.87 \\
Cholesterol (mg/ & 113.98 & 114.41 & 117.01 & $99.13 \pm$ \\
dL) & \pm 7.46 & \pm 9.27 & \pm 5.41 & 6.54 \\
Total Protein (g/ & $5.19 \pm$ & $5.21 \pm$ & $5.40 \pm$ & $5.51 \pm$ \\
dL) & 0.16 & 0.16 & 0.16 & 0.16 \\
Creatinine (mg/ & $0.66 \pm$ & $0.68 \pm$ & $0.80 \pm$ & $0.51 \pm$ \\
dL) & 0.04 & 0.10 & 0.01 & 0.64 \\
BUN (mg/dL) & $14.54 \pm$ & $16.78 \pm$ & $15.23 \pm$ & $14.32 \pm$ \\
& 0.53 & 5.56 & 1.98 & 0.65 \\
\hline
\end{tabular}

Table 3. Time dependent effects of essential oil of Citrus limettioides Tanaka on biochemical parameters in mice at the dose of $0.33 \mathrm{ml} / \mathrm{kg}$

All values are expressed as mean \pm standard error, where $n=8$. 
5. Stashenko EE, Martinez R, Pinzdn MH, Ramfrez I (1996) Changes in chemical composition of catalytically hydrogenated orange oil (Citrus sinensis). J Chromatography 752: 217-222.

6. Caccioni $D R$, Relationship between volatile components of citrus fruit essential oils and antimicrobial action on Penicillium digitatum and Penicillium italicum. Int J Food Microbiol 43: 73-79.

7. Lota ML, Chemical variability of peel and leaf essential oils of mandarins from Citrus reticulata Blanco. Biochemical Systematics Ecolology 28: 61-78

8. Lota M, de Rocca Serra D, Tomi F, Casanova J: Chemical variability of peel and leaf essential oils of 15 species of mandarins. Biochem Syst Ecol 2001; 29;(1.);77-104.

9. Minh NT, Thanh LX, Une A, Ukeda H, Sawamura M (2002) Volatile constituents of Vietnamese pummel, orange, tangrene and lime oils. Flavour Fragr J 17: 169-174.

10. Vekiari SA, Protopapadakis EE, Papadopoulou P, Papanicolaou D, Panou C, Vamvakias M: Composition and seasonal variation of the essential oil from leaves and peel of a Cretan lemon variety. J Agric Food Chem 2002; 50;(1.);147-53.

11. Buettner A, Mestres M, Guasch AF, Schieberle P (2003) Evaluation of the most odour-active compounds in the peel oil of clementines (Citrus reticulata Blanco cv. clementine). Eur Food Res Technol 216: 11-14.

12. Merle H, Moron M, Blazquez MA, Boira H (2004) Taxonomical contribution of essential oils in mandarins cultivars. Biochemical Systematics Ecolology 32: 491-497.

13. Pultrini Ade M, Galindo LA, Costa M: Effects of the essential oil from Citrus aurantium L. in experimental anxiety models in mice. Life Sci 2006; 78;(15.);1720-5.

14. Sharma N, Tripathi A: Effects of Citrus sinensis (L.) Osbeck epicarp essential oil on growth and morphogenesis of Aspergillus niger (L.) Van Tieghem. Microbiol Res 2008; 163;(3.);337-44.

15. Reische DW, Lillard DA, Eitenmiller RR (1998) Chemistry, Nutrition and Biotechnology. Marcel Dekker, New York 423-448.

16. Lis-Balchin M, Hart S: Studies on the mode of action of the essential oil of lavender (Lavandula angustifolia P. Miller). Phytother Res 1999; 13;(6.);540-2.

17. Fisher K, Phillips C (2008) Potential antimicrobial uses of essential oils in food: Is citrus the answer? Trends in Food Sci Technol 19: 156-164.

18. Chutia M, Bhuyan PD, Pathak MG, Sharma, TC, Boruah P (2009) Antifungal activity and chemical composition of Citrus reticulata Blanco essential oil against phytopathogens from North East India. Food Sci Technol; 42:777-780.

19. Rehman Z (2006) Citrus peel extract: A natural source of antioxidant. Food Chem; 99:450-454.

20. Simard S, Hachey JM, Collin GJ (1988) The variations of essential oil composition during the extraction process: the case of Thuja occidentalis L. and Abies balsamea L. Mill. J. Wood Technol; 8:561-573.

21. Rota MC, Herrera A, Martenez, RM, Sotomayo JA, Jordan MA (2008) Antimicrobial activity and chemical composition of Thymus vulgaris, Thymus zygis and Thymus hyemalis essential oils. Food Control; 19:681687.

22. Choi SI, Choi JS, Kim SJ, Bae HJ (2011) In vitro antibacterial and antiinflammatory properties of seaweed extract against acne inducing bacteria Propionibacterium acnes. J Environ Biol; 32:313-318.

23. National laboratory for Clinical Laboratory Standards (1998) Reference method for broth dilution and antifungal susceptibility testing of conidiumforming filamentaneous fungi, proposed standard M38P, Wayne, PA, 1-29.

24. Tao N, Liu Y, Zang M (2009) Chemical composition and antimicrobial activities of essential oil from the peel of bingtant sweet orange (Citrus sinensis Osbeck). Int J Food Sci Technol; 44:1281-1285.

25. Obianime AW, Aprioku JS, Esomonu C (2011) The effects of aqueous Ocimum gratissimum leaf extract on some biochemical and haematological parameters in male mice. Asian J Biol Sci 4(1): 44-52.

26. Myoatasyoh JC, Kiplimo JJ, Karubiu NM, Hailstroks TP (2007) Chemical composition and antimicrobial activity of essential oil of Tarchanthus camphorates. Food Chem; 101:1183-1187.

27. Kurita N, Miyaji M, Kurane R, Takahara Y (1981) Antifungal activity of components of essential oils. Agric Biol Chem; 45:945-952.

28. Coles EH (1986) Erythrocytes, leukocytes and bone marrow. Veterinary Clinical Pathology. W.B. Saunders Company, Philadelphia, 4: 10-97.

29. Bush BM (1991) Interpretation of Laboratory Results for Small Animal. Clinician Blackwell Scientific Publications, London.

\section{Citation:}

Vasudeva $\mathrm{N}$ and Sharma T: Chemical Composition and Antimicrobial Activity of Essential Oil of Citrus limettioides Tanaka. journal of Pharmaceutical Technology and Drug Research 2012, 1:2. http://dx.doi.org/10.7243/2050-120X-1-2 